\title{
High School Students' Knowledge and Its Influence on Attitude towards Biodiversity at Waterfront Cities in Malaysia
}

\author{
Ahmad Zamri Khairani*, Massitah Kipli, Hasni Shamsuddin \\ School of Educational Studies, University of Science, Malaysia
}

Received September 22, 2019; Revised December 1, 2019; Accepted December 4, 2019

Copyright $\bigcirc 2020$ by authors, all rights reserved. Authors agree that this article remains permanently open access under the terms of the Creative Commons Attribution License 4.0 International License

\begin{abstract}
In many cases, urbanization at waterfronts causes conflict that has an impact on its biodiversity. Therefore, the younger generation needs to understand the balance between development and biodiversity at the waterfronts. Thus, the purpose of this study was to investigate high school students' knowledge and their attitude towards biodiversity at waterfront cities. Data was collected from 751 high school students (male $=379$, female $=372$ ) in three states in Malaysia. A self-developed questionnaire with 25 items was administered to gauge information from the students. We also investigate the influence of their knowledge on attitude as well as the effect of gender. Results showed that the students have high knowledge and positive attitude towards biodiversity at waterfront cities. Knowledge was found to be the significant predictor that explains $13.4 \%$ variance in attitude towards biodiversity. Besides that, female students are found to have significantly higher knowledge score than male students, but there was no significant difference in their attitude towards biodiversity. Therefore, we suggest that continuous biodiversity awareness programs should be rooted in school activities to ensure that waterfronts cities preserve their biodiversity.
\end{abstract}

Keywords Biodiversity, Waterfront Cities, Knowledge, Attitude, High School Students

\section{Introduction}

Waterfront cities are a great place to visit since they provide strategic location that have both land and water elements with fascinating environment. Apart from being the catalyst of economic development, waterfront cities offer impressive architectural design with an abundance of aesthetical qualities that could attract ardent visitors. Moreover, waterfronts are usually surrounded by cafes, seats, markets, walkways and other features that offer good amenities for the public to experience. For these reasons, waterfronts have been identified as important criteria that need to be taken into consideration in designing a city [1].

Cruising along with history as far back as an ancient civilization, human has always been in a strong relationship with waterfronts [2]. Earliest human settlements are often found along the waterfronts due to the fact that water is the primary source of survival [3]. Waterfront is often used interchangeably with other terms such as city port, riverside and harbor front by different authors [4]. Notwithstanding, waterfront is clearly defined as a stretch of land that has contact with the body of water such as sea, river, lake, bay, or creek [5]. However, many argue that waterfront should not be seen only as a line on the edge of body of water. Rather, waterfront should be seen in a more diverse perspective such as: (1) places i.e. midpoint between the shoreline and the city, and (2) functions i.e. recreational, cultural, and residential. There is a strong reason for this as authors such as [6] as well as [7] acknowledge the rise of urban waterfront redevelopment occurrences worldwide. Major cities in the world such as Sydney, London, Amsterdam, Hong Kong and Osaka are the testament of waterfront development. In Malaysia, there are a considerable number of waterfront cities such as The Light in Penang, Puteri Harbor and Danga Bay in Johore as well as waterfronts in other major cities in Pahang, Terengganu, Sarawak and Sabah.

According to [8], waterfronts are considered as a zone of interaction between water and urban development. Unfortunately, in many cases, this interaction produces a disastrous effect, especially on its biodiversity. Driveways, patios and streets which are typically associated with urbanization, prevent water from penetrating the soil. This affects the hydrological cycle, that is, the exchange of 
water between land, water bodies, and the atmosphere. Consequently, the volume of water that percolates into the ground decreases resulting in the reduction in the quality of surface water that eventually strains the biodiversity. For example, research by [9] shows that coastal urbanization has resulted in the loss of biodiversity by changing the community structure of microalgae in the southern coastal cities of Brazil. Similarly, [10] speculate that urbanization is the main culprit behind the loss of biodiversity in Indian cities particularly waterfront city, Kolkata which is located on the River Hooghly eastern bank.

In a broader sense, biodiversity is defined as a study on species or other components [11]. More than that, biodiversity refers to all lives on earth from animals, plants to the microorganism with approximately three to 100 million species that interact together with nature [12]. Biodiversity is an important topic among researchers from various backgrounds because of its ability to influence lives as well as its massive impact on global issues such as ecology balance, public health, agriculture, as well as climate change [13]. Thus, biodiversity has been considered as an essential pathway to sustainability [14].

But since the past decades, biodiversity has been on the declining phase [15]. Tragically, human is considered as the main cause of the biodiversity problem [16] particularly due to human activities including urbanization as well as the introduction of invasive species or removal of local species at the waterfronts. [17] concur by maintaining that most urbanization takes place in biodiversity hotspots that disrupt the ecological system and reducing the benefits that human can gain from nature. For example, with regards to waterfront cities, the influx of visitors may have resulted in pollution as well as damage to the natural habitat. Therefore, a comprehensive urban planning and policy regulation is imperative [17].

Regrettably, waterfront cities development in Malaysia is lacking in regulations [2]. For that reason, in order to safeguard biodiversity at waterfront cities, environmental education is the better alternative and is deemed vital in creating awareness regarding the need to preserve biodiversity at waterfront cities while at the same time inculcating environmental attitude among high school students. Thus, the purposes of this study are:

1. To identify the extent on which the students show knowledge and positive attitude towards biodiversity at waterfront cities.
2. To assess the influence of knowledge on attitude towards biodiversity at waterfront cities among high school students.

Biodiversity was introduced to high school students in Malaysia through Alam dan Manusia (Nature and Humans) subject since 1983 [18]). The main objective of this subject is to instil awareness towards the environment in such a way that society can maintain a harmonious life together with the continuous preservation of the environment. Environmental education which provided students with knowledge and awareness so that they can appreciate the environment better was also familiarized [19]. However, the Alam dan Manusia subject was later abolished in 1995 and the environmental education was integrated into other subjects such as languages, moral study, religious study, geography, as well as civic and citizenship in 2005 [20]. In addition, the environmental education was also nurtured through environmental club activities in every school, awareness campaigns as well as talks and educational tours [21]. Apart from the Ministry of Education, the Ministry of Natural Resources and Environment was also involved in cultivating positive attitudes by championing innumerable campaigns, camps, and projects related to the environment.

\section{Materials and Method}

In this study, the sample consisted of 751 high school students with $(n=379)$ males and $(n=372)$ females from the state of Penang, Kedah, and Perak, which are situated on the northern part of Malaysia. Most of the students are of Malay descendant $(n=493)$, followed by Chinese $(n=113)$, Indian $(n=61)$, and others $(n=84)$. Data were collected during teaching and learning session to ensure good returns. The students were briefed and shown how to answer the questionnaire. Simultaneously, students were encouraged to ask questions if they are not able to understand any particular item in the questionnaire. Before attempting the questionnaire, the participants were informed about the objectives and nature of the study. A set of self-developed questionnaire was employed to measure the students' knowledge and attitude towards biodiversity at waterfront cities as conceptualizes and operationalizes in Table 1. It took about 30 - 35 minutes for the students to complete the questionnaire. They were then thanked for their participation in the study. Data were analyzed by using descriptive statistics as well as independent sample $t$-test and simple linear regression.

Table 1. Definition and Operationalization of the Construct of Knowledge and Attitude

\begin{tabular}{cccc}
\hline Variable & Definition & No of Item & Example of Item \\
\hline Knowledge & $\begin{array}{c}\text { The ability of respondents to agree with } \\
\text { the statement about biodiversity at the } \\
\text { waterfront cities }\end{array}$ & 10 & $\begin{array}{c}\text { Increasing number of trees will attract more } \\
\text { species of animals such as birds to come to the } \\
\text { waterfront cities }\end{array}$ \\
\hline Attitude & $\begin{array}{c}\text { Tendencies expressed by evaluating the } \\
\text { biodiversity of the waterfront cities }\end{array}$ & 15 & $\begin{array}{c}\text { The coastal town should not be decorated with } \\
\text { species of trees from oversea }\end{array}$ \\
\hline
\end{tabular}




\section{Results}

Result from the descriptive analysis showed that the students provided the highest mean score of $M=3.47, S D$ $=.68$ on Item A5 (Planting trees can reduce temperature in the surrounding areas) which indicate that they have high knowledge regarding the importance of trees to reduce the temperature at waterfront cities. The students also know the effect of a high number of vehicles at the waterfront cities as depicted by Item A9 (High number of vehicles at waterfront cities increases the possibility of haze) with a mean score of $M=3.33, S D=.74$. Correspondingly, the students again showed their knowledge regarding the importance of trees at waterfront cities as presented by a high mean score of $M=3.30, S D$
$=.64$ for Item A3 (Increasing the number of trees will attract more animal species such as birds to come to the waterfronts).

In contrast, the students have little knowledge on the impact of imported plants on waterfront cities based on the lowest mean score of $M=2.20, S D=.75$ for Item 10 (Imported plants grown in waterfront cities do not interfere with the natural balance). The students also had a lack of information on the impact of motor vehicle on the water at waterfront cities (Item A4 based on the low mean score of $2.79(S D=.80)$. In addition, the student again exhibited a lack of knowledge on the impact of imported species towards biodiversity at waterfront cities (Item $\mathrm{A} 8, M=2.85, S D=.81$ ).

Table 2. Students' Knowledge of Biodiversity

\begin{tabular}{|c|c|c|c|c|c|c|}
\hline \multirow{2}{*}{ Item } & \multicolumn{4}{|c|}{ Percentages of Responses } & \multirow{2}{*}{ Mean } & \multirow{2}{*}{$S D$} \\
\hline & SD & $\mathrm{D}$ & A & SA & & \\
\hline A5: Planting trees can reduce the temperature in the surrounding areas & 2.3 & 3.9 & 38.6 & 55.3 & 3.47 & .68 \\
\hline $\begin{array}{l}\text { A9: High number of vehicles at waterfront cities increases the possibility } \\
\text { of haze. }\end{array}$ & 14.5 & 51.4 & 29.4 & 4.7 & 3.33 & .74 \\
\hline $\begin{array}{l}\text { A3: Increasing the number of trees will attract more animal species such } \\
\text { as birds to come to the waterfronts. }\end{array}$ & 1.6 & 5.5 & 54.2 & 38.7 & 3.30 & .64 \\
\hline $\begin{array}{l}\text { A7: The diversity of animals will be maintained if the trees and other } \\
\text { crops are not cut off from the waterfront cities }\end{array}$ & 1.7 & 6.3 & 52.2 & 39.8 & 3.30 & .66 \\
\hline $\begin{array}{l}\text { A1: Water-filled areas such as mangroves are breeding home to fish and } \\
\text { prawns. }\end{array}$ & 1.6 & 8.4 & 59.1 & 30.9 & 3.19 & .65 \\
\hline $\begin{array}{l}\text { A2: The flow of water will be disrupted if the river or sea near the cliff } \\
\text { is blocked or elevated }\end{array}$ & .9 & 15.3 & 59.3 & 24.5 & 3.07 & .66 \\
\hline $\begin{array}{l}\text { A6: Any bush or small forest in the waterfronts will help species to } \\
\text { survive }\end{array}$ & 2.0 & 12.1 & 63.6 & 22.2 & 3.06 & .65 \\
\hline $\begin{array}{l}\text { A8: Imported fish species can be added to the watershed to increase the } \\
\text { diversity of fish }\end{array}$ & 4.8 & 27.4 & 46.1 & 21.7 & 2.85 & .81 \\
\hline A4: The use of water motor vehicles is a source of water pollution. & 5.2 & 29.3 & 46.9 & 18.6 & 2.79 & .80 \\
\hline $\begin{array}{l}\text { A10: Imported plants grown in waterfront cities will interfere with the } \\
\text { natural balance }\end{array}$ & 4.0 & 28.6 & 51.1 & 16.2 & 2.20 & .75 \\
\hline
\end{tabular}

Notes: $\mathrm{SD}=$ Strongly Disagree; D = Disagree; QD = Quite Disagree; QA = Quite Agree; A = Agree, SA = Strongly Agree; $S D=$ Standard Deviation.

Meanwhile, results also showed that in general, the students demonstrated a positive attitude towards biodiversity at waterfront cities based on high mean scores for the related items. For example, the students agreed that it is not right to dump garbage into the river (Item $\mathrm{B} 3, M=3.58, S D=.77$ ). Another significant finding from this study was that almost all of the students $(91.8 \%)$ acknowledged that both plants and animal have the same rights as human (Item B14, $M=$ $3.34, S D=.70)$. However, it is also important to look at the two least scored Item B12 $(M=2.03, S D=.87)$ and Item B2 $(M=2.14, S D=.77)$. It seems that these items represent the students' expositions that they want to see beautiful waterfronts without thinking of ways to achieve it. 
Table 3. Students' Attitude towards Biodiversity

\begin{tabular}{|c|c|c|c|c|c|c|}
\hline Item & $\mathrm{SD}$ & $\mathrm{D}$ & A & SA & Mean & $S D$ \\
\hline B3: We cannot dump garbage into a river or sea & 3.3 & 7.6 & 16.4 & 72.7 & 3.58 & .77 \\
\hline B14: Plants and animals also have the same rights as humans to exist & 2.4 & 5.9 & 47.3 & 44.5 & 3.34 & .70 \\
\hline $\begin{array}{l}\text { B7: The authorities should increase the number of trees in the waterfront } \\
\text { cities }\end{array}$ & 1.2 & 5.3 & 55.8 & 37.7 & 3.30 & .62 \\
\hline B8: Waterfront cities should be provided with a recreational park & 1.3 & 9.2 & 57.7 & 31.8 & 3.20 & .65 \\
\hline B10: More pedestrian areas should be provided in the waterfront cities & 2.1 & 14.9 & 50.9 & 32.1 & 3.13 & .73 \\
\hline $\begin{array}{l}\text { B9: The many trees should be planted at waterfront cities since they are } \\
\text { great in attracting a variety of animals }\end{array}$ & 1.6 & 14.9 & 60.1 & 23.4 & 3.05 & .67 \\
\hline B15: I believe the balance of nature is very fragile and easily disturbed & 2.7 & 16.5 & 57.4 & 23.4 & 3.02 & .71 \\
\hline $\begin{array}{l}\text { B4: The use of motor vehicles will help to accelerate movement in water } \\
\text { areas }\end{array}$ & 4.7 & 15.8 & 62.7 & 16.8 & 2.92 & .71 \\
\hline B13: Humans have the right to modify nature according to their needs & 5.5 & 24.9 & 42.5 & 27.2 & 2.91 & .86 \\
\hline $\begin{array}{l}\text { B6: Wild plants should be cleared to preserve the beauty of waterfront } \\
\text { cities }\end{array}$ & 7.5 & 28.8 & 40.6 & 23.2 & 2.79 & .88 \\
\hline $\begin{array}{l}\text { B1: Coastal banks should be elevated to provide a wider development } \\
\text { site }\end{array}$ & 4.7 & 29.4 & 51.4 & 14.5 & 2.76 & .75 \\
\hline $\begin{array}{l}\text { B11: Roads around waterways should be closed to vehicles to prevent } \\
\text { air pollution }\end{array}$ & 7.2 & 34.4 & 40.9 & 17.6 & 2.69 & .84 \\
\hline $\begin{array}{l}\text { B5: Waterfront cities should be decorated with trees imported from } \\
\text { abroad }\end{array}$ & 5.6 & 38.1 & 46.9 & 9.5 & 2.60 & .74 \\
\hline $\begin{array}{l}\text { B2: The use of traditional boats to cross the river should be replaced by } \\
\text { the construction of bridges }\end{array}$ & 18.0 & 55.1 & 21.7 & 5.2 & 2.14 & .77 \\
\hline B12: Weed poisons need to be used regularly to keep the coastline clean & 30.0 & 43.0 & 20.6 & 6.4 & 2.03 & .87 \\
\hline
\end{tabular}

This study also investigates the influence of knowledge on attitude towards biodiversity at waterfront cities. We reported that knowledge is a significant predictor for attitude $(\beta=.366, p=.000)$ and the variable explains $13.4 \%$ variance in attitude towards biodiversity at waterfront cities. Finally, an independent sample $t$-test was carried out to compare the effect of gender and attitude towards biodiversity at waterfront cities. For knowledge, result showed that the mean difference is statistically significant $[t(749)=-3.853, p=.000]$. It explains that the mean score of the female students $(M=31.02, S D=3.19)$ is significantly higher than their male counterparts $(M=$ $30.12, S D=3.24)$. Nevertheless, we found no significant difference in the mean score of attitude towards biodiversity $[t(749)=-1.330, p=.184]$ between the male $(M=43.39, S D=3.87)$ and the female $(M=43.75, S D=$ 3.59) students.

\section{Discussion}

Based on the descriptive statistics reported earlier, it can be deduced that majority of the students established high knowledge with regards to the involvement of the aspects of plants and animals at the waterfront cities as revealed in high mean score for items A5, A3, A7, A6, and $\mathrm{A} 10$. We consider this as a positive finding since trees are known to improve soil and help conserve water. Moreover, trees absorb ambient air pollutant such as nitrogen dioxide (NO2), sulfur dioxide (SO2), and carbon monoxide [22], while at the same time release oxygen for animals' respiration. In other words, the trees act as purifier against the pollutant gasses, which possibly were released from motor vehicles as well as industries in the nearby city centers. Further, the integration of trees and agriculture (known as agroforestry), has been increasingly recognized as an important development that not only help in increasing income and food security but also encourage conservation of biodiversity [23].

Nevertheless, result from this present study also showed that the students have little knowledge regarding the impact of imported plants on biodiversity. They concede that the imported plants, or commonly known as invasive plants have little impact on the natural balance as described in Item A10. Introducing invasive plants may be able to beautify the waterfront area and provide a unique experience for its visitors yet, it should be noted that invasive plants have a much bigger adverse impact on biodiversity. Introducing invasive species have been known to affect animals that were highly adapted to the native trees. Likewise, releasing imported fishes at waterfront cities (Item A8) was also considered harmful since the species were also known to disrupt the balance of biodiversity by feeding on local fishes.

Generally, the students presented favorable responses with regards to attitude towards biodiversity, based on high mean scores for the related items. Specifically, the students also demonstrated high mean scores with regards to trees and animals at the waterfront cities. For example, they understand the need to respect the rights of trees and animal (Item B14) as well as the need to increase the number of trees. This positive attitude might stem from 
their existing knowledge about biodiversity.

One interesting observation from the findings of this study was that the students seem to think of waterfront cities as a beautiful place to visit. Thus, they expect the waterfront cities to be decorated with something unique such as imported trees. At the same time, they also want to see these waterfronts clean and well taken care of. Yet, it seems that they somehow do not know the proper way to accomplish this. As mentioned earlier, even though planting invasive trees might be able to attract visitors, the practice might compromise biodiversity.

Other than that, the students seem to put emphasize on their mobility while at waterfront cities. For example, they recommended that it is important to have motor vehicles as this will help to accelerate movement in water areas (Item B4) while the fact is that the pollution caused by motor vehicles will disrupt the water quality around the waterfront cities. As a result, microorganisms may perish and subsequently, aquatic species such as fish, shrimp or snails will also diminish. Then again, the students' emphasis on their mobility at waterfront cities was further shown by a high percentage of agreement for Item B10 (More pedestrian areas should be provided in the waterfront cities). To a certain extent, this is a positive finding since it indicates the students' attitude towards a more comfortable urban environment without vehicle congestion.

Studies on the influence of knowledge and attitudes about biodiversity and environment in general always produce significant and positive results as reported by [24], [25], and [26]. Interestingly, results from the present study also produce a similar pattern. One possible explanation for this is that knowledge is considered as a function of beliefs and experiences [27]. This is why knowledge was primarily assessed through the number of attitude-relevant beliefs and experiences people can recall [28].

The present study reports that female students demonstrate higher knowledge scores compared to their male counterparts. The result is consistent with a study on environmental attitudes by [15]. Nonetheless, this study also revealed that there is no significant difference regarding attitude towards biodiversity at waterfront cities between the male and female students. This is considered as an unexpected finding since we postulate that the female score should be higher since attitude is relatively influenced by greater knowledge. In this case, even though the female students have better knowledge on biodiversity than their male counterparts, they were not able to transfer it to their attitude. This warrants further investigation since the results may indicate the weakness in environmental education in Malaysia.

\section{Conclusions}

Findings of this study indicate that the students have high knowledge and positive attitude towards biodiversity at waterfront cities. They demonstrated their knowledge and attitude particularly towards the importance of trees. However, the students seem to have a lack of understanding on the impact of invasive species at the waterfront cities. Hence, environmental education at the earliest stage is crucial in cultivating the awareness and the Ministry of Education should be more serious in implementing this aspect of erudition in the national syllabus.

Besides, in this study, we are able to present empirical evidence that the students' knowledge about biodiversity at waterfront cities has a significant influence on their attitude. In light of this, continuous biodiversity awareness programs should be rooted in school activities as the more they know about the importance of biodiversity, the more they appreciate the waterfront cities. Further, schools may engage with local city councils to share the information on the natural habitat and species at the waterfront cities with the school students to increase their understanding of biodiversity.

Finally, we are also able to confirm that female students have significantly higher knowledge about biodiversity than the male students. Notwithstanding, the female students were not able to translate their better knowledge into a more positive attitude. Further studies could be done in addressing this concern. Subsequently, we also provide propositions on how findings of this study can inform stakeholders to improve the effectiveness of environmental education in schools. Undoubtedly, the future of biodiversity lies in the hands of the young generation, thus a study on their knowledge and attitude is very substantial and more studies with the same interests are highly recommended.

\section{Acknowledgements}

This work was supported by Transdisciplinary Research Grant Scheme Eco-Environmental Conservation in The Selected Waterfront Cities in Malaysia 203.PBIOLOGI.67611003 from Ministry of Education. We also thank Universiti Sains Malaysia for making this research possible.

\section{REFERENCES}

[1] Girard, L. F., Kourtit, K., \& Nijkamp, P. (2014). Waterfront areas as hotspots of sustainable and creative development of cities. Sustainability, 6(7), 4580-4586.

[2] Azlina, M. Y., \& Mohd Asrul Nasid, M. (2013). Waterfront development in Malaysia: Examining laws and regulation. In 2nd International Conference on Sustainable Infrastructure and Built Environment 2013. Bandung, Indonesia. Retrieved from http://eprints.uthm.edu.my/4618/1/SIBE-_Azlina_Md._Ya 
ssin.pdf

[3] Kostopoulou, S. (2013). On the revitalized waterfront: Creative milieu for creative tourism. Sustainability, 5(11), 4578-4593.

[4] Timur, U. P. (2013). Urban waterfront regenerations. In M. Özyavuz M. (Ed.) Advances in landscape architecture (pp 169-205). Rijeka: InTech.

[5] Shaziman, S., Usman, I. M. S., \& Tahir, M. (2010). Waterfront as public space: Case study Klang River between Masjid Jamek and Central Market, Kuala Lumpur. Paper presented at the 6th WSEAS International Conference on Energy, Environment, Ecosystems and Sustainable Development (EEESD' 2010) and 3rd WSEAS International Conference on Landscape Architecture (LA' 2010), 21st-23rd October, Politehnica University of Timisoara, Romania, retrieved from

www.wseas.us/e-library/conferences/2010/TimisoaraP/...E ELA-56.pdf.

[6] Gospodini, A. (2001). Urban waterfront redevelopment in Greek cities. A framework for redesigning space. Cities, 18(5), 285-295.

[7] Giovinazzi, O., \& Moretti, M. (2010). Port cities and urban waterfront: Transformation and opportunities. TeMaLab Journal of Mobility, Land Use and Environment, 3(SP), 57-64.

[8] Yassin, A. M., Eves, C. \& McDonagh, J. (2010). An evolution of waterfront development in Malaysia. Paper presented at the 16th Pacific Rim Real Estate Society Conference (24th-27th January), Intercontinental Hotel, Wellington, New Zealand.

[9] Martins, C. D. L., Arantes, N., Faveri, C., Batista, M. B., Olive, E., Pagliosa, P. R., Fonseca, A. L., Nunes, J. M. C., Chow, F., Pereira, S. B., \& Hortaa, P. A. (2012). The impact of coastal urbanization on the structure of Phytobenthic Communities in Southern Brazil. Marine Pollution Bulletin, 64(4), 772-778.

[10] Paul, S., \& Bardhan, S. (2017). Biodiversity accounting of cities: A case study of Kolkata, India. WIT Transactions on Ecology and the Environment, 226(1), 815-826.

[11] Worm, B., \& Branch, T. A. (2012). The future of fish. Trends in Ecology and Evolution, 27(11), 594-599.

[12] Convention on Biological Diversity. (2011). Biodiversity in Cities: A Biodiversity Exhibition Project Among Leader Cities. Montpellier, France. Retrieved from https://www.cbd.int/authorities/doc\%5CPresentationsBonn Meeting\%5CBernal.pdf

[13] Peterson, A. T. (2003). Predicting the Geography of Species' Invasions via Ecological Niche Modeling. Quarterly Review of Biology, 78(4), 419-433.

[14] Siegel, M. (2006). High school students' decision making about sustainability. Environmental Education Research, 12(2), 201-215.

[15] Aznar-Díaz, I., Hinojo-Lucena, F.-J., Cáceres-Reche, M.-P., Trujillo-Torres, J.-M., \& Romero-Rodríguez, J.-M. (2019). Environmental attitudes in trainee teachers in primary education: The future of biodiversity preservation and environmental pollution. International Journal of
Environmental Research and Public Health Article, 16(3), E362.

[16] Eldredge, N. (2000). Life in the balance. Princeton: Princeton University Press.

[17] Nilon, C. H., Aronson, M. F. J., Cilliers, S. S., Dobbs, C., Frazee, L. J., Goddard, M. A., et al. (2017). Planning for the future of urban biodiversity: A global review of city-scale initiatives. BioScience, 67(4), 332-342

[18] Aini, M. S., Nor Azura, S. \& Fakhru'1-Razi, A. (2011). Impact of environmental education on concern, knowledge and sustainable behavior of primary school children. Health and the Environment Journal, 2(1), 50-53.

[19] Rosnani, I. (2006). Pendidikan alam sekitar. Kuala Lumpur: Era Hijau.

[20] Ministry of Education (2004). The development of education: National report of Malaysia. Putrajaya: Ministry of Education.

[21] Mohammad Zohir, A. \& Nordin, A. R. (2007). Pendidikan alam sekitar di sekolah: Komitmen guru. Pendidikan Lestari, 7(2), 74-81.

[22] Chen, T., Kushner, W. G., Gokhale, J., \& Shofer, S. (2007). Outdoor air pollution: Nitrogen Dioxide, Sulfur Dioxide, and Carbon Monoxide health effects. The American Journal of Medical Sciences, 333(4), 249-256.

[23] Kuyah, S., Oborn, I., Jonsson, M., Dahlin, A. S., Barrios, E., Muthuri, C., Malmer, A., Nyaga, J., Magaju, C., Namirembe, S, et al. 2016. Trees in agricultural landscapes enhance provision of ecosystem services in Sub-Saharan Africa. International Journal of Biodiversity Science, Ecosystem Services \& Management, 12(4), 255-273.

[24] Barr, S., 2007. Factors influencing environmental attitude and behaviour: A UK case study of household waste management. Environment Behaviour, 39(4), 435-473.

[25] Aminrad, Z., Zakariya, S. Z. S., Abdul Samad Hadi, A. S., \& Sakari, M. (2013). Relationship between awareness, knowledge and attitudes towards environmental education among secondary school students in Malaysia. World Applied Science Journal, 22(9), 1326-1333.

[26] Venustea, N., Oliviera, H., \& Valens, V. (2017). Knowledge, attitudes and awareness of pre-service teachers on biodiversity conservation in Rwanda. International Journal of Environmental \& Science Education, 12(4), 643-652.

[27] Krosnick, J. A., \& Pretty, R. E. (1995). Attitudes strength: An overview. In R. E. Pretty and J. A. Krosnick (eds), Attitude strength: Antecedents and consequences (pp. 1-24). Mahwah, NJ: Erlbaum.

[28] Kallegren, C. A., \& Wood, D. (1986). Access to attituderelevant information in memory as a determinant of attitude-behaviour consistency. Journal of Experimental Social Psychology, 22, 328-338. 